\title{
Location Analysis of City Public Transport Shelters in Commercial Corridors (Case Study: Dr. Wahidin Street, Pekalongan City)
}

\author{
Ardiana Yuli Puspitasari $^{1 *}$, Eko Arief Budiarto ${ }^{2}$, and Rachmat Mudiyono ${ }^{3}$ \\ ${ }^{1,2}$ Urban and Regional Planning of Sultan Agung Islamic University, Jl. Raya Kaligawe Km,4 Semarang, \\ Indonesia \\ ${ }^{3}$ Civil Engineering Department of Sultan Agung Islamic University, Jl. Raya Kaligawe Km,4 Semarang, \\ Indonesia \\ *Corresponding author: ardiana@unissula.ac.id
}

(Received: $14^{\text {th }}$ January 2021 ; Accepted: $29^{\text {th }}$ April 2021)

\begin{abstract}
Dr. Wahidin Street is one of the important corridors in Pekalongan City and passed by the city's public transportation. When viewed the arrangement of land use in the vicinity, this corridor is dominated by trade, services, housing, education, and office activities. This makes the potential for population attraction and movement using public transportation modes in this road corridor relatively large. However, along the corridor, currently, only 1 (one) shelter is available, and it is rarely used by passengers. The main reason is that the distance to the existing shelter is too far. Currently, passenger boarding and disembarking activities are still carried out in any place so that they often obstruct traffic flow and endanger passengers. The purpose of this study is to determine the number and location of shelters to accommodate the needs of passengers in the corridor of Dr. Wahidin Street, Pekalongan. The analysis method in this research is a quantitative analysis using the Set Covering Problem and analysis tools using ArcGis and Lingo 8.0 software. The results showed that the number of shelters needed was 4 (four) units with 2 locations each in the West of the road (Dr. Wahidin Shelter and in front of PPIP Wholesale Market) and 2 in the East of the road (around the Pandu Shop and the Honda Dealer).
\end{abstract}

Keywords: Shelters; Public Transportation; Location Analysis.

\section{Introduction}

Dr. Wahidin Street is one of the important corridors in Pekalongan City because of its status as a national road and as one of the strategic areas for economic growth based on trade in services as stipulated in the 2011-2021 City Spatial Plan for Pekalongan City. Has dimensions of 1,230 meters long and 14 meters wide with a function as a primary arterial road [6].

Based on the distribution of routes by Department of Transportation Pekalongan City, this corridor is one of the corridors that the city public transport passes. When viewed from the arrangement of land use in the vicinity, this corridor is dominated by trade, services, housing, education and offices activities. This makes the potential for population attraction and movement using public transportation modes in this road corridor relatively large. However, along this corridor, currently only 1 (one) bus stop is available, and it is rarely used by passengers. The main reason for the rarely use of these stops is that the distance to the bus stops is too far. Currently, passenger boarding and descending activities are still carried out at random places, so they often 
obstruct traffic flow and endanger passengers, considering the volume of vehicles passing through this corridor is quite busy.

When viewed from passenger preferences in choosing a city public transport stop location, passengers prefer to stop at any place or there is no stop facility, this is due to the closer distance to the destination so it is not tiring, but from a safety and comfort point of view it is not necessarily good [4]. Therefore, the researcher wanted to analyze the exact location and number of bus stops required in the commercial corridor of Dr. Wahidin Street Pekalongan City for the convenience of transportation users.

\section{Literature Review}

\subsection{Public Transport Shelters}

Shelters are included in the transportation infrastructure component that must be provided to assist the performance of the broader regional transportation system framework. The shelter is a stopover for public transportation to drop off or pickup passengers equipped with a building [3]. The existence of shelter can minimize disruption to smooth traffic. With the shelter, it makes it easy for public transport drivers to find potential passengers. Besides that, it also makes it easy for public transport passengers to find the public transportation needed to continue their journey. For this reason, the shelter needs to be equipped with adequate and precise facilities and infrastructure as well as a location adapted to the existing environment in the area concerned. Arrangements for public transport stops need to be adjusted to the needs, therefore it is necessary to pay attention to the provisions: 1) types of shelters; 2) distance between shelters; 3 ) criteria for determining the location of the shelters; and 4) shelter facilities.

\subsubsection{Types of Shelter}

Determining the types of public transport stops depends on the level of needs of the users, the availability of land, and the environmental conditions that affect it. Types of bus stops are divided into 2 types [1]:

1) Shelter with protection (shelter), is a stop in the form of a building used by passengers to wait for buses or other public transportation that can protect them from the weather.

2) A non-protected stop (bus stop), is a stopover that is used for temporary stops of buses or other public transportation at the time of raising and dropping off passengers.

\subsubsection{Distance Between Shelter}

The distance between shelter is the distance between one shelter and the next or previous shelter. In general, the things that must be considered are [1]: 1) the location of the shelters are relatively close and still possible to reach people on foot with their luggage; 2) the location of the shelters does not make it difficult for the driver to operate public transport vehicles; 3) shelter capacity and demand are based on needs; 4) economical level for the operation of shelters.

By looking at the description above, the distance between the shelters can also be adjusted as in the following table: 
Table 1. Distance of Shelter based on Activity

\begin{tabular}{clccc}
\hline Zone & \multicolumn{1}{c}{ Activity } & Location & Type of Stop & Distance of Stop (m) \\
\hline 1 & High-density service activities & CBD, City & $\begin{array}{c}\text { With Protection } \\
\text { (Shelter) }\end{array}$ & $200-300$ \\
\hline 2 & Medium-density mixed activites & City & $\begin{array}{c}\text { With Protection } \\
\text { (Shelter) }\end{array}$ & $300-400$ \\
\hline 3 & Top-class mixed activities & City & $\begin{array}{c}\text { Unprotected } \\
\text { (Bus Stop) }\end{array}$ & $300-400$ \\
\hline 4 & Medium-density mixed activities & Periphery & $\begin{array}{c}\text { With Protection } \\
\text { (Shelter) }\end{array}$ & $300-500$ \\
\hline 5 & Low-density mixed activities & Periphery & $\begin{array}{c}\text { Unprotected } \\
\text { (Bus Stop) }\end{array}$ & $500-1000$ \\
\hline
\end{tabular}

\subsubsection{Criteria for Determining the Location of Shelters}

1) Based on City Conditions

Determining the location of shelters is carried out by taking into account the location requirement plan, passenger activity network nodes, public transportation routes, and meeting the following general requirements [9]: a) Crowded centers, such as markets, shops, tourism objects, and others; b) Activity Centers, such as offices, schools, trade, etc; and c) Ease of access to public transportation modes such as at crossroad.

Other requirements in determining the location of a stop, in general, must fulfill the following matters [1]: a) Located on a pedestrian path/sidewalk (footway); b) Close to the center of activities that generate public transport users; c) Not hidden and safe against crime; d) There must be regulators for the movement of vehicles, stop users, and pedestrians, so that they are safe against traffic accidents; and e) Does not interfere with smooth traffic.

Apart from the general requirements as above, technical guidelines can also be used to determine the location of the stop technically [3]: a) The maximum distance between the shelter and pedestrian crossing facilities is 50 meters; b) Preferably provide bus lay bay; c) The minimum distance of the stop from the road meeting is 50 meters or according to the length of the queue; d) The minimum distance between the shelter and the building that requires quiet is 100 meters.

By looking at the general requirements (non-technical) \& practical (technical) guidelines for the location of public transport stops, it is expected the shelter will not cause problems for the flow of traffic that is on the route of stopping public transportation and provide comfort and safety for service users. Shelters that take place on the side of the road, will physically take a portion of the road capacity [4]. Therefore it is necessary to refer to the applicable provisions relating to the regulations of the Ministry of Transportation.

\section{2) Based on Passenger Origin and Destination}

In determining the exact location of the stop based on the origin and destination of the passenger, it is necessary to have information about the origin and destination of the passenger along with the customs of the waiting location. The number of passengers and their origin will go to the waiting location on the road, which is the route for public transportation and is easily accessible for changing modes. The destination of traveling passengers is very dependent on the interests of traveling, so the speed of departure time encourages prospective passengers to choose a location that is easily accessible. The number, origin, destination of passengers, and route of public transportation routes can serve as a basis for obtaining alternative bus stops that are easy to reach, safe, and in accordance with the needs of passengers and the public transport itself. 


\subsubsection{Shelter Facilities}

To ensure the comfort and safety of passengers while waiting, getting on and off public transportation, and ensuring smooth traffic accessibility, so that the function of shelters becomes more effective and efficient, it is necessary: a) The waiting place for passengers does not interfere with road activities; b) Adequate shelter; c) Safe and smooth stopping places for public transportation; d) Passenger seats to wait; e) crossing facilities for pedestrians that are not disturbed by shelter activities; f) Installation of fences so that pedestrians do not cross anywhere, and; g) Information and a public telephone if required.

The dimensions of the shelters are adjusted to the needs which are very dependent on the number of passengers and the activity of public transportation according to the route. The stop which is equipped with a lay bay bus is intended to provide security.

\subsection{Passengers}

There are two passengers for public transportation, namely intra-city and inter-city passengers, while the public transportation system can be individual or mass depending on the need and type of transportation. Public transportation passengers will pay for public transportation services in accordance with predetermined conditions. The nature and purpose of traveling from passengers can be different even in one public transportation, for example, a) Work trips; b) School Trips; and c) Travel and other things. For the smooth and clarity of the journey, passengers need a place to get on and off public transportation that is sure, fast, and safe.

\subsubsection{Duration of Passengers to Board and Disembark Public Transportation}

The time required for passengers to disembark from public transportation is 2.5-4 seconds and 3 seconds to board. For other public transportation, for example, water transportation and air transportation, it is certainly different from land transportation. The time referred to above does not include the time to sit and stand up from the seat of public transportation, but only the time it takes for a person to get in and out of public transportation, which is usually only seconds [5].

\subsubsection{Passengers Walking Distance}

The maximum distance that a person can travel by walking and carrying their luggage to the waiting area for public transportation is 300 meters [9]. Meanwhile, the details of the maximum passenger walking distance are influenced by the length of the itinerary and the type of area [10]. The table below states that the longer the travel distance with public transportation to be taken, prospective passengers are willing to walk farther, and in table 3 the denser an area the shorter the distance that must be traveled by prospective passengers.

Table 2. Distance to be Travelled

\begin{tabular}{clc}
\hline No & Distance to be Travelled & Maximum Walking Distance \\
\hline 1 & $<5 \mathrm{~km}$ & $500 \mathrm{~m}$ \\
\hline 2 & $5-10 \mathrm{~km}$ & $750 \mathrm{~m}$ \\
\hline 3 & $>10 \mathrm{~km}$ & $1.000 \mathrm{~m}$ \\
\hline
\end{tabular}

Table 3. Maximum Walking Distance

\begin{tabular}{clc}
\hline No & \multicolumn{1}{c}{ Tipe Area } & Jarak Jalan Maksimum \\
\hline 1 & CBD & $400 \mathrm{~m}$ \\
\hline 2 & Settlement & $600 \mathrm{~m}$ \\
\hline 3 & Sub Urban & $800 \mathrm{~m}$ \\
\hline
\end{tabular}


Table 4. Criteria for Determining the Location of the Shelter

\begin{tabular}{|c|c|c|c|}
\hline No & Parameter & Variable & Indicator \\
\hline 1. & $\begin{array}{l}\text { Shelter } \\
\text { Location }\end{array}$ & $\begin{array}{l}\text { 1. There is in Landuse } \\
\text { that has a potential } \\
\text { trip generation } \\
\text { 2. Usual location of } \\
\text { passengers waiting } \\
\text { for public } \\
\text { transportation }\end{array}$ & $\begin{array}{l}\text { Crowded location and considered valid as a shelter } \\
\text { location with a high level of demand. }\end{array}$ \\
\hline \multirow[t]{2}{*}{2.} & $\begin{array}{l}\text { Criteria of } \\
\text { Shelter } \\
\text { Location }\end{array}$ & 1) Technical Criteria & $\begin{array}{l}\text { (1) Minimum distance of the stop from the } \\
\text { meeting street is } 50 \mathrm{~m} \text { or adjusted to the length } \\
\text { of the queue; } \\
\text { (2) Minimum distance of the bus stop with the } \\
\text { building that requires tranquility is } 100 \mathrm{~m} \text {. }\end{array}$ \\
\hline & & $\begin{array}{l}\text { 2) Non-Technical } \\
\text { Criteria }\end{array}$ & $\begin{array}{l}\text { (1) Located in the center of the existing crowds, } \\
\text { such as markets, shops, tourist attractions and } \\
\text { others; } \\
\text { (2) Located in the center of activities, such as } \\
\text { offices, schools, trade etc.; } \\
\text { (3) Ease of access to public transportation modes, } \\
\text { for example at crossroads. }\end{array}$ \\
\hline
\end{tabular}

\section{Methodology}

The research method used in this study is rationalistic quantitative deductive method.
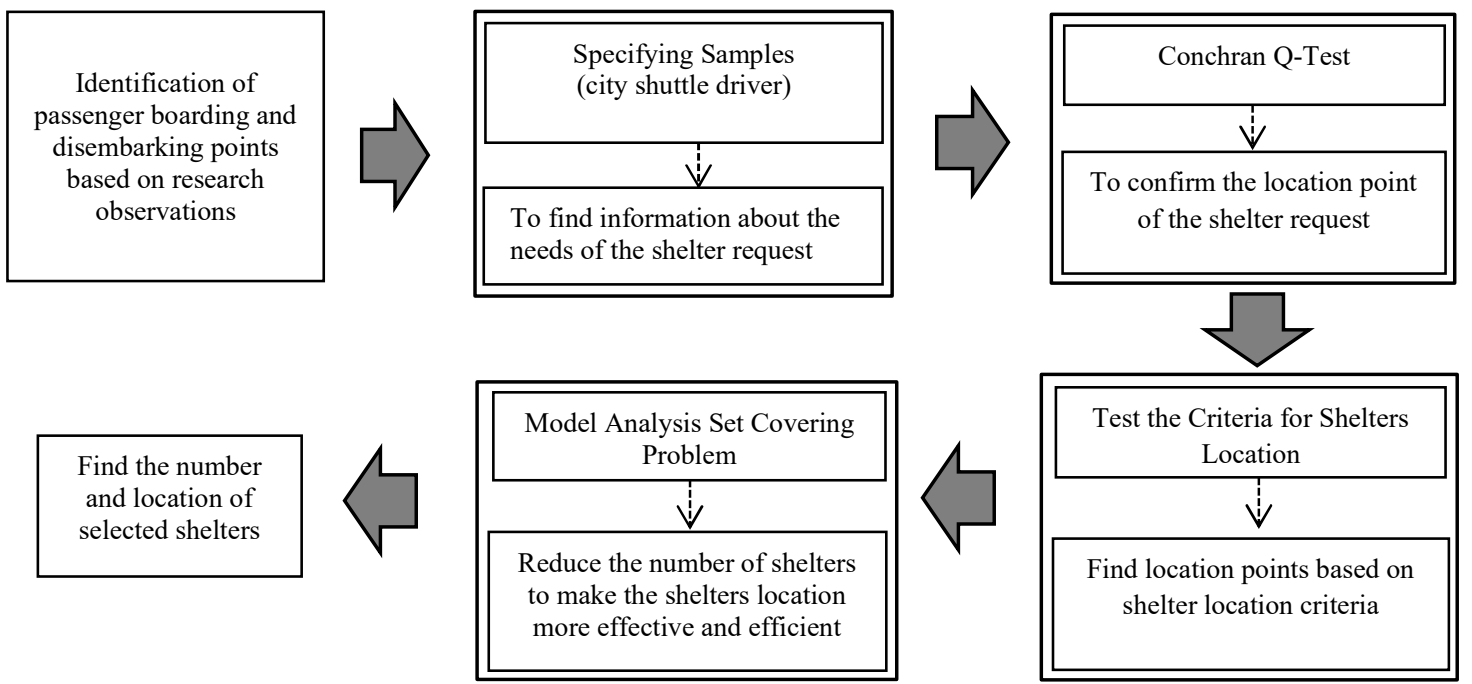

Fig. 1. Analysis Process Chart

The number of samples for respondents is determined by the formula of the Slovin mathematical function approach [8] as follows:

$$
n=\frac{N}{1+N d^{2}}
$$

Where:

$\mathrm{n}=$ Number of samples

$\mathrm{N}=$ Number of population (370 transport drivers)

$\mathrm{d}^{2}=$ Error tolerance $(10 \%)$ 
$n=\frac{370}{1+\left(370 \times 10 \%^{2}\right)}=78,72 \approx 80$

Analytical Techniques:

1) Cochran Q-Test

The Cochran Q-Test was performed on the questionnaire data obtained from respondents regarding the point of request for shelters that are mostly used by public transport passengers. In the Cochran Q-Test, closed questions are given to respondents, where the choice of questions for which the answer has been provided. To find out which of the selected locations, performed Cochran Q-Test was with the following procedure [7]:

1) The hypothesis to be tested:

$\mathrm{H}_{0}$ : all the tested attributes have the same proportion of "Yes" answers

$\mathrm{H}_{1}$ : not all tested attributes have the same proportion of "Yes" answers.

2) Look for $\mathrm{Q}$ counts with the following formulas:

$$
\mathrm{Q}=\frac{k-1\left|\sum_{i}^{k} C_{i}^{2}-\left(\sum_{i}^{k} C_{i}\right)^{2}\right|}{k \sum_{i}^{n} R_{i}-\sum_{i} R_{i}^{2}}
$$

$\mathrm{Q}=\mathrm{Q}$ counts

$\mathrm{k} \quad=$ Number of attributes to count

$\mathrm{R}_{\mathrm{i}}=$ Number of "yes" on all attributes to 1 Respondent

$\mathrm{C}_{\mathrm{i}} \quad=$ Number of "yes" on 1 attribute for all Respondents

3) Determination of Q table (Qtab)

With $\alpha=0,05$, Degrees of freedom $(\mathrm{dk})=\mathrm{k}-1$, then obtained Q table $(0.05: \mathrm{df})$ from the table Chi Square Distribution.

4) Decision:

Reject $\mathrm{H} 0$ and accept H1, if Q calculates $>\mathrm{Q}$ table

Accept $\mathrm{H} 0$ and reject $\mathrm{H} 1$, if Q calculates $<\mathrm{Q}$ table

5) Conclusion:

- If $\mathrm{H} 0$ is rejected means the proportion of "Yes" answers is still different on all attributes. That is, there has been no agreement among respondents about attributes.

- If $\mathrm{HO}$ is accepted then the proportion of "Yes" answers on all attributes is considered the same. Thus, all respondents are considered to agree on all attributes as a factor to consider.

\section{2) Set Covering Problem Analysis}

This analysis technique is the stage of determining the optimal location of the shelter. The goal is to find access between the nearest shelters that are easily accessible to all passengers but with a minimum number of shelters (effective). Set Covering Problem (SCP) is the result of the development of facility location theory developed by Daskin [2].

The formulations used are as follows:

$I \quad=$ Demand point with $i$ index

$j \quad=$ Alternate location point with $j$ index

$D_{i j} \quad=$ Distance between $i$ request point and $j$ location alternative

$D_{c} \quad=$ Fulfillment distance

$N_{i} \quad=\left\{j \mid d_{i j}\right\} \leq D_{c}$ 
$=$ All location alternatives that include $i$ request points

The decision variables:

$$
X_{j}=\left\{\begin{array}{l}
1 \text { If match at the location } j \\
0 \text { If it does not match at the location } j
\end{array}\right.
$$

With the above notation, it can be formulated as follows:

Minimize

$$
\sum_{j e J} X_{j}=x 1+x 2+x 3
$$

Subject to

$$
\begin{gathered}
\sum_{j e J N i} X_{j} \geq 1 \forall i \in I \\
X_{j} \in\{0,1\} \forall j \in J
\end{gathered}
$$

Based on these formulations can be described into a function of purpose

Eq. (3) to minimize the number of alternate locations.

Eq. (4) each request point can be fulfilled by at least one facility,

Eq. (5) true or false a decision.

For the limit function stipulates that the distance between a minimum of 500 meters (Regulation of the Minister of Public Works year 2011 on Road Technical Requirements and Road Technical Planning Criteria).

\section{Results and Discussions}

\subsection{Analysis of Potential Sources of Trip Generation}

The type of land use along the corridor of Dr. Wahidin Street is dominated by trade and service activities, in addition there are also office areas, education, health, and settlements. In the context of the room, an area can be a source trip generation when there are many activities in it, so that the pattern of land use of an area / city will affect the travel patterns of people.

\subsection{Identify the Location Point of the Passenger's Boarding and Disembarking}

There are 28 locations that are usually places where passengers board and disembark public transportation in Dr.Wahidin Street.

Table 5. Location Point of the Passenger's Boarding and Disembarking

\begin{tabular}{llll}
\hline \multicolumn{2}{l}{ East Side } & \multicolumn{2}{l}{ West Side } \\
\hline Point & Location & Point & Location \\
\hline L1 & Near "Simpang Empat" & L1 & Accros "Posis" \\
\hline L2 & $\begin{array}{l}\text { At Dr.Wahidin Shelter (Existing } \\
\text { Shelter) }\end{array}$ & L2 & Around "Rajawali" Shop \\
\hline L3 & $\begin{array}{l}\text { Around "TK Aisyiyah Bustanul } \\
\text { Atfhal" }\end{array}$ & L3 & $\begin{array}{l}\text { In front of "SMP Muhammadiyah } \\
\text { Noyontaan" }\end{array}$ \\
\hline L4 & Around "ABA" Shop & L4 & In front of "Puskesmas Noyontaan" \\
\hline L5 & Around "Toys" Shop & L5 & Around "Pandu" Shop \\
\hline L6 & Around "Habib" Shop & L6 & Around "Jaya" Shop \\
\hline L7 & Near railway & L7 & Around "Mina" Shop \\
\hline L8 & In front of "PPIP” Wholesale Market & L8 & Around "Berkah" Shop \\
\hline
\end{tabular}




\begin{tabular}{llll}
\hline \multicolumn{2}{l}{ East Side } & \multicolumn{2}{l}{ West Side } \\
\hline Point & Location & Point & Location \\
\hline L9 & Around "SMA Hasyim Asy'ari" & L9 & Near railway \\
\hline L10 & $\begin{array}{l}\text { Aroudn "Panti Asuhan Yatim } \\
\text { Muhammadiyah" }\end{array}$ & L10 & Around Honda's Dealer \\
\hline L11 & Around "Surya" Shop & L11 & Around "Happy" Shop \\
\hline L12 & Around Village Office & L12 & In front of Jaya Dipa Hotel \\
\hline L13 & Around "Makmur" Shop & L13 & In front of Jaya Dipa Hotel \\
\hline L14 & Around "Posis" & L14 & Around Ganesh Operation (GO) \\
\hline
\end{tabular}

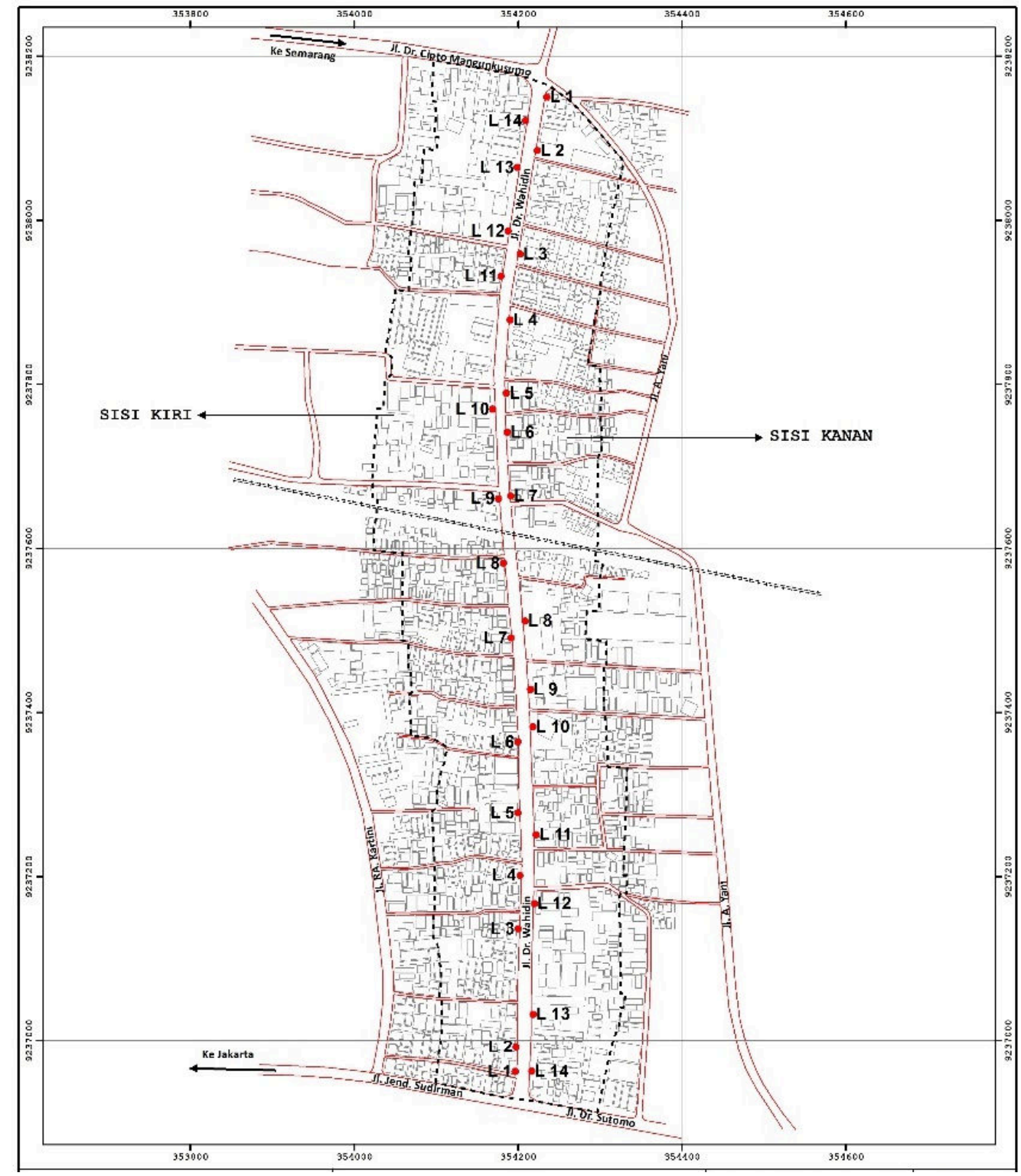

Fig. 2. Location Point of the Passenger's Boarding and Disembarking 


\subsection{Location Test with Cochran Q-Test}

In this Cochran Q-Test test method aims to find out if there is an agreement of answers chosen by the respondents. Based on the observations, there are 28 locations where passengers can get on and off public transportation. Then the question was distributed to respondents (public transport drivers) in the form of questionnaires to find out if these locations are indeed considered often used as places to board and disembark passengers with relatively large numbers. The conclusion of this Cochran Q-Test is that all respondents agree. Based on cochran Q-Test results, the location can be considered valid as a location with a relatively high level of demand.

\subsection{Determination of Prospective Shelter Location Points that Meet the Criteria}

\subsubsection{Assess Locations with Predetermined Criteria}

After testing using cochran Q-Test method against the location considered by respondents as a location with a relatively high level of demand, then the next step is to assess the location points using predetermined criteria (see table 4).

Table 6. East Side Location Assessment Based on Location Criteria

\begin{tabular}{|c|c|c|c|c|c|c|}
\hline \multirow{3}{*}{ Location } & \multirow{3}{*}{ Description } & \multicolumn{5}{|c|}{ Location Criteria } \\
\hline & & \multicolumn{2}{|c|}{$\begin{array}{l}\text { Technical } \\
\text { Criteria }\end{array}$} & \multicolumn{3}{|c|}{$\begin{array}{c}\text { Non-Technical } \\
\text { Criteria }\end{array}$} \\
\hline & & 1 & 2 & 1 & 2 & 3 \\
\hline \multirow[b]{2}{*}{$\mathbf{L 1}$} & Near "Simpang Empat" & $\mathrm{X}$ & $\checkmark$ & $\mathrm{X}$ & $\mathrm{X}$ & $\checkmark$ \\
\hline & \multicolumn{6}{|c|}{$\begin{array}{l}\text { - Located at a highway intersection, is feared to impede the smooth running of traffic; } \\
\text { - This location is not located in the center of the crowd or activities such as markets, } \\
\text { offices or schools; } \\
\text { - So, this location is considered less feasible because it has not met all the criteria. }\end{array}$} \\
\hline $\mathbf{L} 2$ & $\begin{array}{l}\text { At Dr.Wahidin Shelter (Existing } \\
\text { Shelter) }\end{array}$ & $\checkmark$ & $\checkmark$ & & & $\checkmark$ \\
\hline L3 & $\begin{array}{l}\text { Around "TK Aisyiyah Bustanul } \\
\text { Atfhal" }\end{array}$ & $\checkmark$ & $\checkmark$ & & & $\checkmark$ \\
\hline L4 & Around "ABA" Shop & $\checkmark$ & $\checkmark$ & & & $\checkmark$ \\
\hline $\mathbf{L 5}$ & Around "Toys" Shop & $\checkmark$ & $\checkmark$ & & & $\checkmark$ \\
\hline L6 & Around "Habib" Shop & $\checkmark$ & $\checkmark$ & & & $\sqrt{ }$ \\
\hline \multirow[b]{2}{*}{ L7 } & Near railway & $\mathrm{X}$ & $\checkmark$ & & & $\checkmark$ \\
\hline & \multicolumn{6}{|c|}{$\begin{array}{l}\text { This location is less than } 100 \mathrm{~m} \text { from the railway crossing, it is feared that there is a } \\
\text { buildup of queues of vehicles when there are trains passing by, so this location should } \\
\text { not be chosen; } \\
\text { - So, this location is considered less feasible because it does not meet all the criteria. }\end{array}$} \\
\hline L8 & In front of "PPIP" Wholesale Market & $\checkmark$ & $\checkmark$ & & & $\checkmark$ \\
\hline \multirow[b]{2}{*}{ L9 } & $\begin{array}{l}\text { Around "Hasyim Asy'ari” Senior High } \\
\text { School }\end{array}$ & $\checkmark$ & $\mathrm{X}$ & & & $\checkmark$ \\
\hline & \multicolumn{6}{|c|}{$\begin{array}{l}\text { - This location is less than } 100 \mathrm{~m} \text { from the Muhammadiyah Orphanage Mosque, so it is } \\
\text { feared that it can disturb the tranquility; } \\
\text { - So, this location is considered less feasible because it does not meet all the criteria. }\end{array}$} \\
\hline \multirow{2}{*}{ L10 } & $\begin{array}{l}\text { Around "Panti Asuhan Yatim } \\
\text { Muhammadiyah" }\end{array}$ & $\checkmark$ & $\mathrm{X}$ & & & $\checkmark$ \\
\hline & \multicolumn{6}{|c|}{$\begin{array}{l}\text { - In this orphanage complex there is a Mosque, so it is feared that it can disturb the } \\
\text { tranquility; }\end{array}$} \\
\hline
\end{tabular}




\begin{tabular}{|c|c|c|c|c|c|c|c|}
\hline \multirow{3}{*}{ Location } & \multirow{3}{*}{ Description } & \multicolumn{6}{|c|}{ Location Criteria } \\
\hline & & \multicolumn{2}{|c|}{$\begin{array}{c}\text { Technical } \\
\text { Criteria }\end{array}$} & \multicolumn{4}{|c|}{$\begin{array}{c}\text { Non-Technical } \\
\text { Criteria }\end{array}$} \\
\hline & & 1 & 2 & 1 & 2 & & \\
\hline & \multicolumn{7}{|c|}{ - So, this location is considered less feasible because it does not meet all the criteria. } \\
\hline L11 & Around "Surya" Shop & $\checkmark$ & $\checkmark$ & $\checkmark$ & & & $\checkmark$ \\
\hline L12 & Around Village Office & $\checkmark$ & $\checkmark$ & $\checkmark$ & & & $\checkmark$ \\
\hline \multirow[t]{2}{*}{ L13 } & Around "Makmur" Shop & $\checkmark$ & $\checkmark$ & $\checkmark$ & & & $\checkmark$ \\
\hline & Around "Posis" & $\mathrm{X}$ & $\checkmark$ & $\checkmark$ & & & $\checkmark$ \\
\hline L14 & \multicolumn{7}{|c|}{$\begin{array}{l}\text { - Its location less than } 50 \mathrm{M} \text { from the highway intersection is feared to impede the } \\
\text { smooth running of traffic; } \\
\text { - So, this location is considered less feasible because it does not meet all the criteria. }\end{array}$} \\
\hline
\end{tabular}

Table 7. West Side Location Assessment by Location Criteria

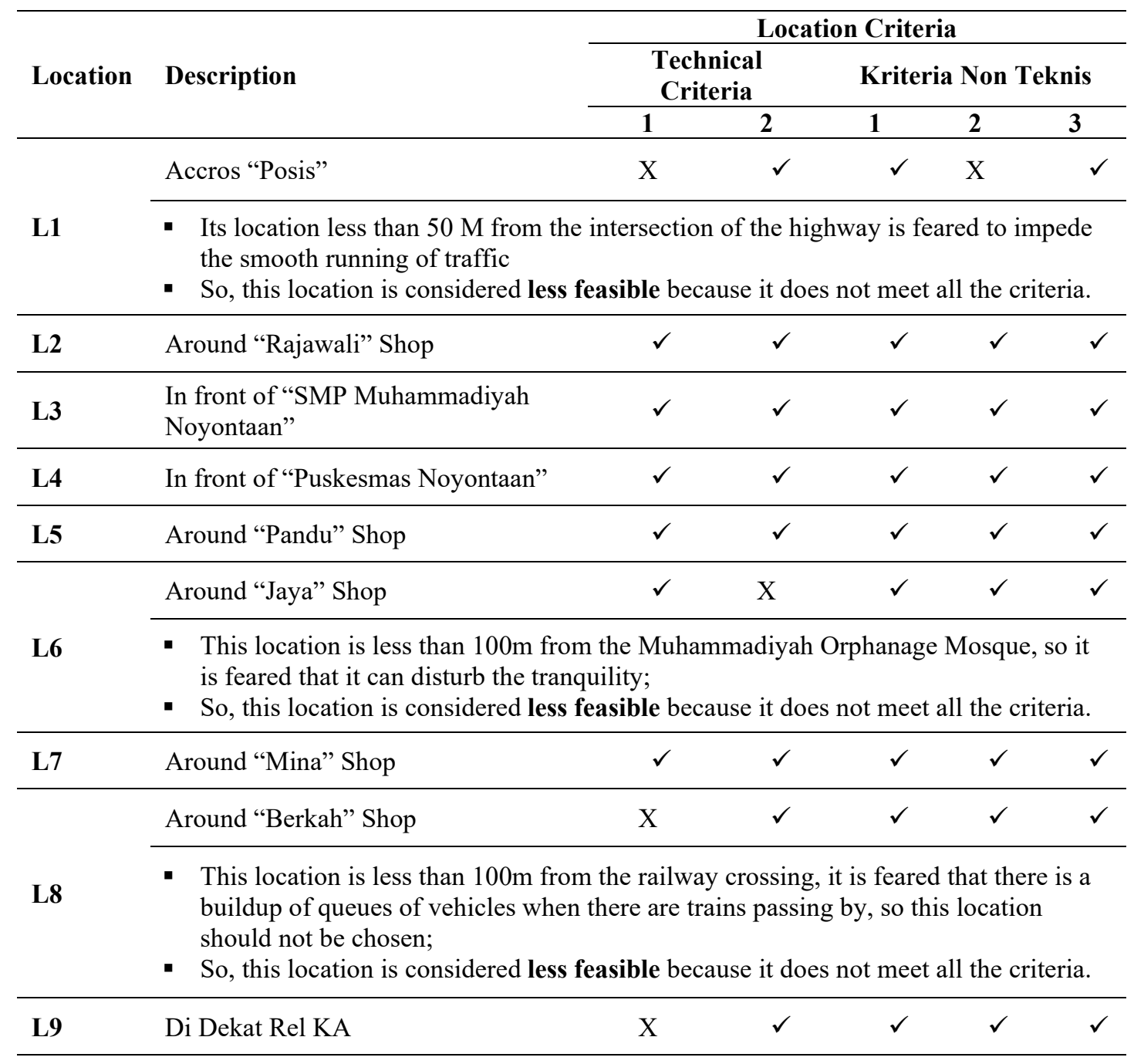




\begin{tabular}{|c|c|c|c|c|c|}
\hline \multirow{3}{*}{ Location } & \multirow{3}{*}{ Description } & \multicolumn{4}{|c|}{ Location Criteria } \\
\hline & & $\begin{array}{l}\text { Technical } \\
\text { Criteria }\end{array}$ & \multicolumn{3}{|c|}{ Kriteria Non Teknis } \\
\hline & & 1 & 1 & 2 & 3 \\
\hline
\end{tabular}

- This location is less than $100 \mathrm{~m}$ from the railway crossing, it is feared that there is a buildup of queues of vehicles when there are trains passing by, so this location should not be chosen;

- So, this location is considered less feasible because it does not meet all the criteria.

\begin{tabular}{llccccc}
\hline $\mathbf{L 1 0}$ & Around Honda's Dealer & $\checkmark$ & $\checkmark$ & $\checkmark$ & $\checkmark$ & $\checkmark$ \\
\hline $\mathbf{L 1 1}$ & Around "Happy" Shop & $\checkmark$ & $\checkmark$ & $\checkmark$ & $\checkmark$ & $\checkmark$ \\
\hline $\mathbf{L 1 2}$ & In front of Jaya Dipa Hotel & $\checkmark$ & $\checkmark$ & $\checkmark$ & $\checkmark$ & $\checkmark$ \\
\hline $\mathbf{L 1 3}$ & In front of Jaya Dipa Hotel & $\checkmark$ & $\checkmark$ & $\checkmark$ & $\checkmark$ & $\checkmark$ \\
\hline & Around Ganesh Operation (GO) & X & $\checkmark$ & $\checkmark$ & $\checkmark$ & $\checkmark$ \\
\hline
\end{tabular}

L14 - Its location less than $50 \mathrm{M}$ from the intersection of the highway is feared to impede the smooth running of traffic

- So, this location is considered less feasible because it does not meet all the criteria.

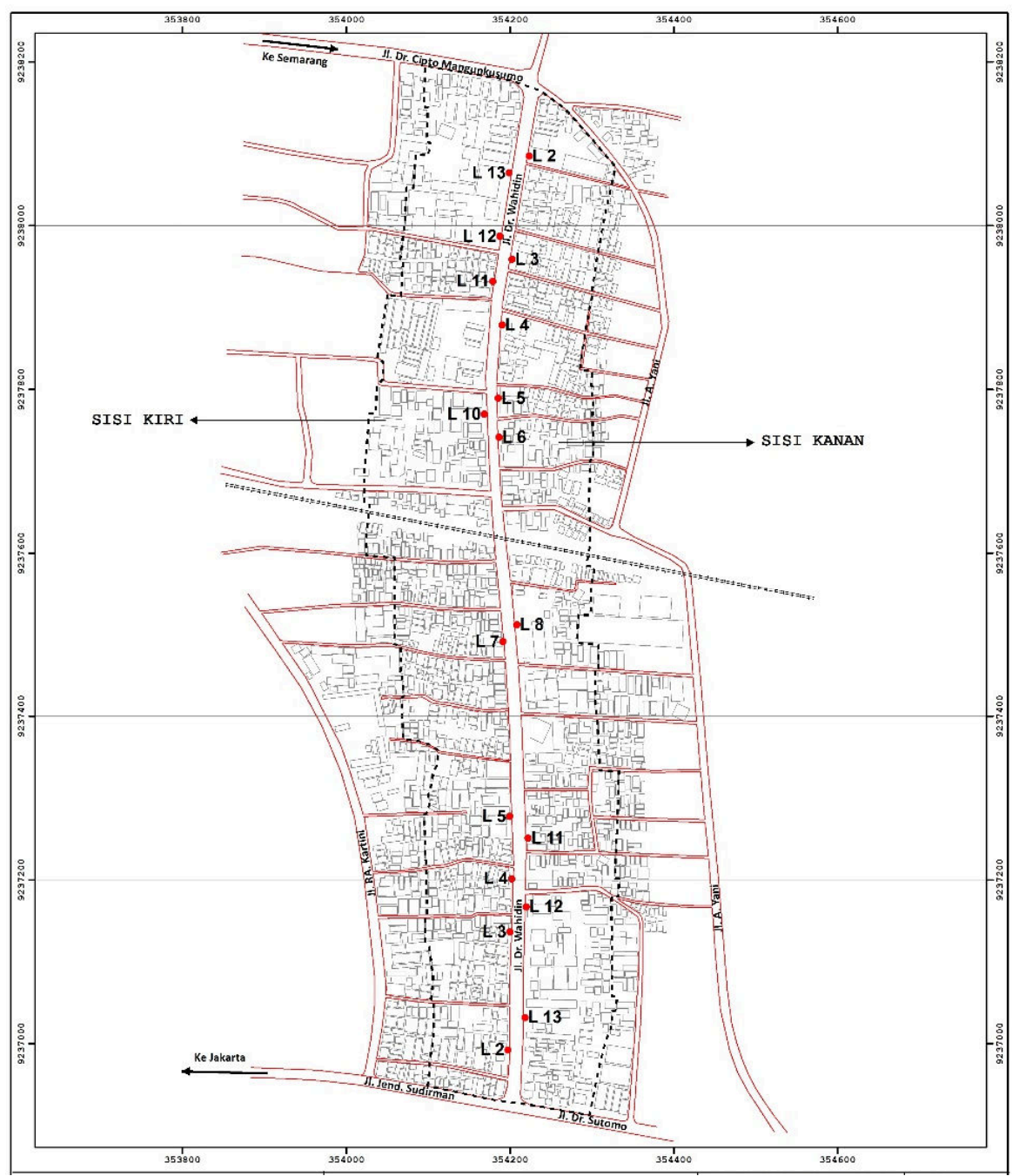

Fig. 3. Location of Requests that Accordance with Criteria 


\subsubsection{Measurement of Distance Between Request Locations in Accordance with Criteria}

Table 8. Measurement of Distance Between Request Locations in Accordance with Criteria

\begin{tabular}{|c|c|c|c|c|c|}
\hline \multirow{2}{*}{ No } & \multicolumn{2}{|c|}{ Distance between Shelters } & \multirow{2}{*}{ No } & \multicolumn{2}{|c|}{ Distance between Shelters } \\
\hline & East Side & Meters & & West Side & Meters \\
\hline 1. & L2 to L3 & 128 & 1. & L2 to L3 & 144 \\
\hline 2. & L3 to L4 & 81 & 2. & L3 to L4 & 64 \\
\hline 3. & L4 to L5 & 90 & 3. & L4 to L5 & 76 \\
\hline 4. & L5 to L6 & 48 & 4. & L5 to L7 & 213 \\
\hline 5. & L6 to L8 & 231 & 5. & L7 to L10 & 279 \\
\hline 6. & L8 to L11 & 261 & 6. & L10 to L11 & 162 \\
\hline 7. & L11 to L12 & 83 & 7. & L11 to L12 & 55 \\
\hline 8. & L12 to L13 & 134 & 8. & L12 to L13 & 78 \\
\hline & Average & 132 & & Average & 133,87 \\
\hline
\end{tabular}

Based on previous analysis, there are 18 locations that meet the criteria of 28 existing locations. Where 9 locations are on the East side of the corridor and 9 other locations are on the West side of the corridor Dr. Wahidin Street. For the East side the average distance between the locations of demand is 132 meters. As for the West side itself the average distance between locations of demand is 133.87 meters.

\subsection{Analysis of Characteristics Public Transport Passengers}

\subsubsection{Number of Passengers on the East Side of the Corridor}

The total number of passengers on the East side of the corridor is 206 people. For the number of passengers who boarded was 109 people (52\%), while for passengers who dropped by 97 people $(48 \%)$. The largest number of places to board and disembark passengers occurred at the point L12 where the number of passengers who boarded and who disembarked amounted to 30 people. Here is a graph of the number of passengers who go up and down at 9 points east side of the corridor.

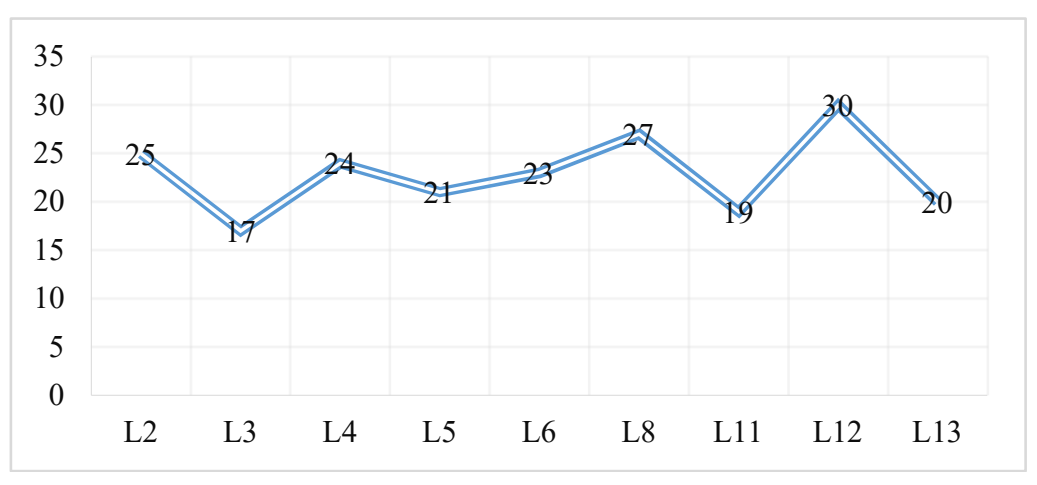

Fig. 4. Number of Passengers on the East Side of the Corridor

The need for passengers in using public transportation to work as much as $18 \%$, while for school as much as $19 \%$. The remaining $63 \%$ are classified with other purposes, such as shopping, visiting family places or for other purposes.

\subsubsection{Number of Passengers on the West Side of the Corridor}

The total number of passengers on the West side of the corridor is 191 people. For the number of passengers who boarded was 99 people (52\%), while for passengers who dropped by 92 people (48\%). The largest number of places to board and disembark passengers occurred at the point L5 where the number of passengers who boarded and who disembarked amounted to 28 people. 


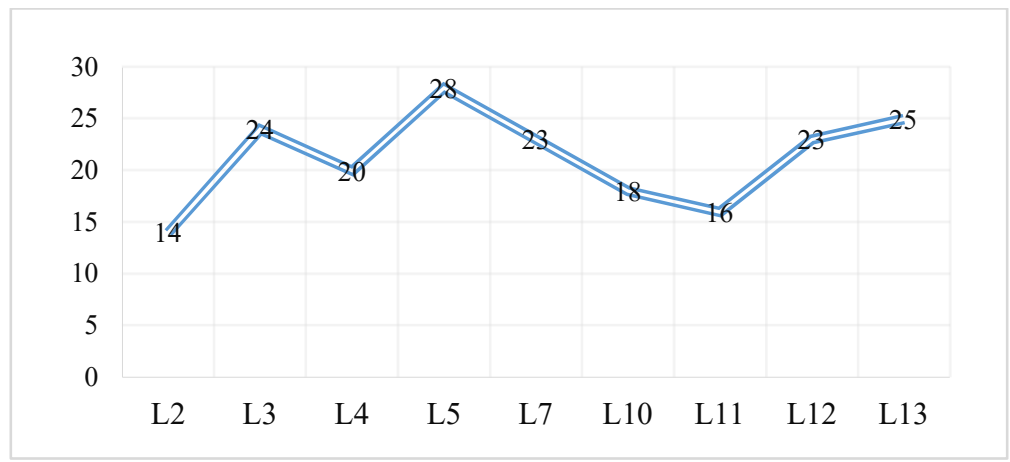

Fig. 5. Number of Passengers on the West Side of the Corridor

The need for passengers in using public transportation to work as much as $18 \%$, while for school as much as $16 \%$. The remaining $66 \%$ are classified with other purposes, such as shopping, visiting family places or for other purposes.

\subsection{Set Covering Problem Analysis}

This analysis technique aims to reduce the number of shelters needed so that it can be more effective and efficient in its implementation, but still be able to meet all points of demand. Solving the problem by using the Branch and Bound method in Lingo 8.0 software, resulted in the following solutions:

\subsubsection{East Side Selected Shelters}

From the processing, the results of the location of the bus stop on the East side of the corridor of Dr. Wahidin Street are selected as shown below.

Global optimal solution found at iteration: objective value:

\begin{tabular}{lll}
\hline Variable & Value & $\begin{array}{c}\text { Reduced Cost } \\
\text { L2 }\end{array}$ \\
L3 & 0.000000 & 1.000000 \\
L4 & 0.000000 & 1.000000 \\
L5 & 0.000000 & 1.000000 \\
L & 0.000000 & 1.000000 \\
L8 & 1.000000 & 1.000000 \\
L11 & 0.000000 & 1.000000 \\
L12 & 0.000000 & 1.000000 \\
L13 & 0.000000 & 1.000000 \\
\end{tabular}

Fig. 6. Lingo 8.0 Optimization Results for the East Side

From the picture above, it can be seen that the location of the selected shelter is 2 locations, namely L2 and L8. Where if the result shows 1.00 indicates that the location of the stop is appropriate at the location but if the result 0.00 it indicates that the location of the stop is not appropriate at the location. For the East side, the average distance between shelters with each other that can be reached by users is $578 \mathrm{~m}$.

\subsubsection{West Side Selected Shelters}

From the processing, the results of the location of the bus stop on the west side of the corridor of Dr. Wahidin Street are selected as shown below: 
Global optimal solution found at iteration: Objective value:
0

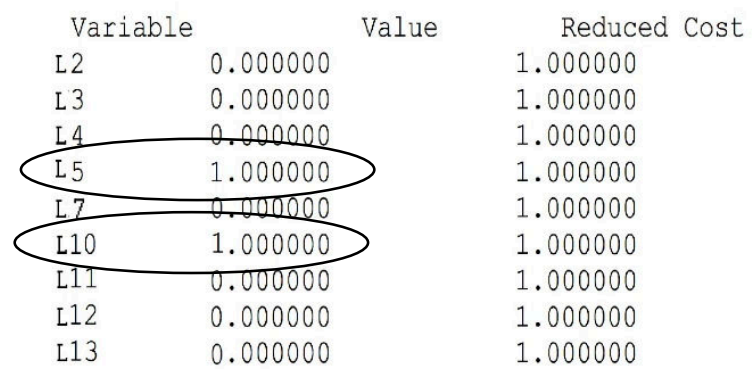

Fig. 7. Lingo 8.0 Optimization Results for the West Side

From the picture above, it can be seen that the location of the selected shelter is 2 locations, namely L5 and L10. Where if the result shows 1.00 indicates that the location of the stop is appropriate at the location but if the result 0.00 it indicates that the location of the stop is not appropriate at the location. For the West side, the average distance between shelters with each other that can be reached by users is $500 \mathrm{~m}$.

\subsection{Profile of Selected Shelter Locations}

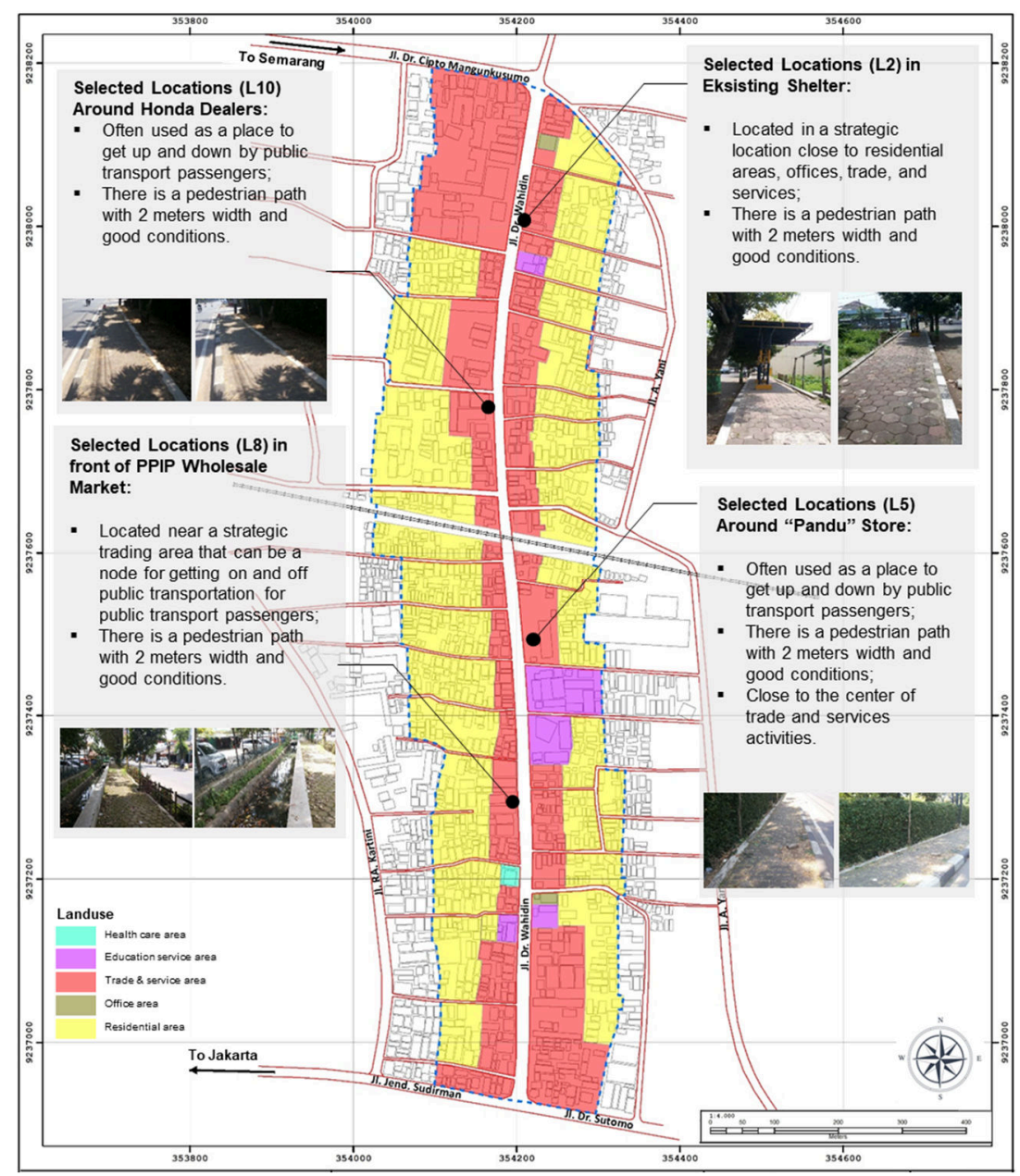

Fig. 8. profile of selected shelter locations 


\section{Conclution and Recommendations}

\subsection{Conclution}

Based on the analysis, the number of shelters needed is as many as 4 points which are spread out in the following locations:

1) East Side Selected Shelter Locations

a) At Dr. Wahidin (existing shelter)

b) In front of PPIP Wholesale Market

2) West Side Selected Shelter Location

a) Around the Pandu Shop

b) Around the Honda Dealer

\subsection{Recommendations}

1) With the discovery of the number and location of shelters on the Dr. Wahidin Street, the government of Pekalongan City is advised to conduct a feasibility study of location and continue with the physical construction of the shelters.

2) The finding of the locations of these shelters needs to be integrated with other elements of environmental quality systems, for example, pedestrian ways, accros bridges, vegetation, etc.

\section{Acknowledgment}

We would like to express our gratitude to Sultan Agung Islamic University as an institution that accommodates researchers to conduct research. Also to the Pekalongan City Department of Transportation and all respondents for the information provided in the research process.

\section{References}

[1] Abubakar, Iskandar (1995), Towards Orderly Traffic-Collection of Materials \& Technical Instructions for Road Traffic \& Transportation, Jakarta: Direktorat Jenderal Perhubungan Darat (in Indonesian).

[2] Daskin, Mark S. (2008), What You Should Know About Location Modelling, Wiley InterScience, Naval Research Logistics, 55:283-294.

[3] Decision of the Director General of Land Transportation No 271/HK.105/DRJD/96, on the Technical Guidelines for the Engineering of Public Passenger Vehicle Stops (in Indonesian).

[4] Hobbs, F.D. (1995). Traffic Planning and Engineering, Yogyakarta: Gadjah Mada University Press (in Indonesian).

[5] Homburger, W.S. (Ed.). (1982). Transportation and Traffic Engineering Handbook (2nd ed.), Englewood Cliffs, New Jersey: Prentice-Hall (in Indonesian).

[6] Pekalongan City Spatial Plan 2011-2021 (in Indonesian).

[7] Simamora, Henry. (2004), Human Resource Management, Yogyakarta: STIE YKPN (in Indonesian).

[8] Sugiyono. (2011), Quantitative, Qualitative and R\&D Research Methods, Bandung: Afabeta (in Indonesian).

[9] Warpani, P. Suwarjoko. (2002), Traffic Management and Public Transport, Bandung: IT (in Indonesian).

[10] Wigenard (1989). Modelling Transport. New York: Wiley. 